\title{
Compressibility of soft Iraqi soil stabilized with traditional Iraqi stabilizers (cement and lime)
}

\author{
Husam Baqir ${ }^{1, *}$, Aqeel Al-Adili ${ }^{1}$ and Ali Sharef ${ }^{2}$ \\ ${ }^{1}$ University of Technology, Baghdad, Iraq \\ ${ }^{2}$ Baghdad Governorate, Directorate of Education, Baghdad, Iraq
}

\begin{abstract}
This study shows an improvement of two types of clay soil brought from different parts of Iraq. The first soil (A) from Al - Zaafaraniya site in Baghdad governorate. The second soil (B) from Garma Ali site in the Al Basra governorate, Iraq. Soft clayey soils were treated by a combination of sulphate resistance Portland cement (PC) and Quicklime (LQ) to modify and stability. PC was added in percentages of 2,4,6,8 and $10 \%$, as well as, LQ was added to 2 and $4 \%$, of dry weight. Laboratory tests to determine specific gravity, Atterbergs limits and standard proctor test were conducted. Also, the main objective of this research is the concentrating on compression ratio (CR), the Rebound (Swelling) ratio (RR) and the stiffness during the modulus of elasticity (Es) for treated and natural soils procreation from consolidation test. The results from laboratory tests shows high ability on the enhancing in terms of reduction in plasticity index (greatly increased workability), reduction in compression ratio (CR), reduction in the Rebound (Swelling) ratio (RR), increase in the modulus of elasticity (Es). The change in moisturedensity relationships resulting in lower maximum dry densities, higher optimum water content, and less variation of dry density from the maximum over a much wider range of water contents.
\end{abstract}

\section{Introduction}

The Soft clay soils are late alluvial deposits presumably formed through the 10,000 years covered by their featureless and flat solid ground surface. Brand and Bernard, (1981) ${ }^{1}$ identified, such clay by their low undrained shear strength $(\mathrm{Cu}<40 \text { Kpa) (B.S.C.P.8004:1986) })^{2}$ and high compressibility (CC between 0.19 to 0.44 ). They are found in high natural moisture content typically ranging from $(40-60) \%$ with the plasticity index, ranging from $(45-65) \%$ (Broms, 1987) ${ }^{3}$. Soils with such characteristics create serious problems to geotechnical engineering associated with stability and settlement problems. Clay soils cause cracking and fracture of pavement, railways, highway embankment, roadways, foundations and channel or reservoir linings (Cokça, 1999) ${ }^{4}$. Solutions to the problems presented by clay subgrades include excavating and replacing a thickness of clay with a select fill material and increasing the base thickness layer to decrease subgrade stresses and minimize moisture changes. Both solutions are inherently expansive and wasteful because they require disposal of significant quantities of inferior materials or the use and transportation of additional virgin materials. For low - volume roads, this expense is especially high because, frequently, the distance of the road project to sources of suitable in situ materials is quite far (Prusinski and Bhattacharja, 1999). To proceed with this alternative, soil stabilization using lime and / or hydraulic binders, etc. is a widespread technique employed to improve the workability and hydromechanical properties of soils (Obuzor et al., 2011) $)^{5}$. Stability with lime and cement are mainly and commonly used in the above-mentioned works and they have been under continuous development since its launch in the middle of the last century. Lime is used primarily to dewater the soil in order to improve the workability and its bearing capacity. This Lime modification is widely used for building embankment and subgrade of clayey soil since the effect is rapid and modifies the geotechnical characteristics of the soil like the plastic limit, the shear strength and the soil compaction characteristics. Later the pozzolanic reaction between the soil minerals and lime in the presence of water leads to the formation of secondary cementitious products (C-S-H, C-A-S-H,...) increasing the soil cohesion and its resistance (Pomakhina et al., 2012) ${ }^{6}$. The effects of the pozzolanic reaction are mainly effective in long term. If the mechanical resistance of the material is essential in short term, the soil stabilization goes through the use of cement. Cement stabilization is quick, does not need mellowing time and provides a non-leaching platform (Sariosseiri and 
Muhunthan, 2009)7. Cement can be used for stabilization of a wide range of soils and the best performances of soils treated with cement have been observed on silt as well as on coarse-grained materials (Currin et al., 1976) ${ }^{8}$. Furthermore, in practice, in the world, a mixed treatment with lime and cement is used since the mixture allows to facilitate the workability without disturbing the effect of the cement in the gain of resistance in the long term.

The addition of lime and cement exerts impacts on the material microstructure. The flocculation/aggregation of clay particles after adding lime or cement modifies, for one thing, the material particle size distribution (Osula, 1996) ${ }^{9}$ and, consequently, influences pore distribution over a very short term (Bin et al., 2007) ${ }^{10}$, although this distribution is evolving during the curing period as well as in jointly with both the pozzolanic and hydraulic reactions (Metelkova et al., 2012) $)^{11}$. Locat et al. (1990) ${ }^{12}$ followed up by representing the lime distribution in a soil sample.

\section{Experiment of investigation}

\subsection{Material used}

\subsubsection{Soils}

In this study two soil samples (A and B) were used obtained from two different locations. The first soil sample (A) from Al - Zaafaraniya site in Baghdad city. The second soil sample (B) from the Garma Ali site about $538 \mathrm{~km}$ south of Baghdad in $\mathrm{Al}$ Basra city. The engineering properties of clayey soils are presented in Table 1 and Figure (1) shows the grain size distribution of soils used.

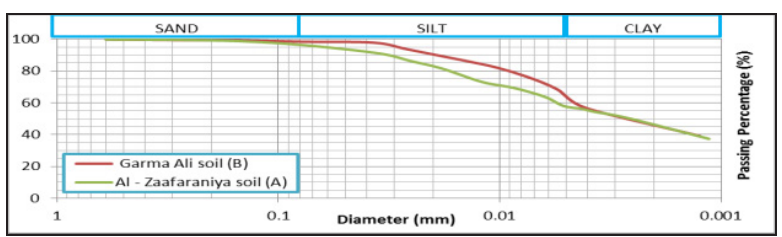

Fig. 1. Particle Size Distribution of Soft Soil used

Table 1. Physical and Chemical Properties of Natural Soils Used.

\begin{tabular}{|c|c|c|c|}
\hline \multirow{2}{*}{ Index Property } & \multirow{2}{*}{ Test Standard } & \multicolumn{2}{|c|}{ Index Valve } \\
\cline { 3 - 4 } & Soil A & Soil B \\
\hline $\begin{array}{c}\text { Natural water } \\
\text { content (\%) }\end{array}$ & ASTM D 2216 & 26 & 31 \\
\hline Depth (m) & --- & \multicolumn{2}{|c|}{$0.5-1.5$} \\
\hline $\begin{array}{c}\text { Liquid Limit } \\
\text { (L.L) (\%) }\end{array}$ & ASTM D 4318 & 48 & 58 \\
\hline $\begin{array}{c}\text { Plastic Limit } \\
\text { (P.L) (\%) }\end{array}$ & ASTM D 4318 & 21 & 27 \\
\hline
\end{tabular}

\begin{tabular}{|c|c|c|c|}
\hline $\begin{array}{c}\text { Plasticity Index } \\
\text { (P.I) (\%) }\end{array}$ & ASTM D 4318 & 27 & 31 \\
\hline $\begin{array}{c}\text { Activity of Clay } \\
\text { (At) }\end{array}$ & $\begin{array}{c}\text { Skempton } \\
\text { formula } \\
\text { At= } \\
\text { of clay }< \\
\text { 0.002mm })\end{array}$ & 0.6 & 0.56 \\
\hline $\begin{array}{c}\text { Specific Gravity } \\
\text { (G.s) }\end{array}$ & ASTM D 854 & 2.72 & 2.75 \\
\hline $\begin{array}{c}\text { Gravel (larger } \\
\text { than 4.75mm) (G) } \\
\%\end{array}$ & ASTM D 422 & 0 & 0 \\
\hline $\begin{array}{c}\text { Sand (0.075 to } \\
4.75 \text { mm) (S) \% }\end{array}$ & ASTM D 422 & 4 & 2 \\
\hline $\begin{array}{c}\text { Silt (0.005 to } \\
0.075 \text { mm) (M) } \\
\%\end{array}$ & ASTM D 422 & 38 & 35 \\
\hline $\begin{array}{c}\text { Clay (less than } \\
0.005 m m)(C) \%\end{array}$ & ASTM D 422 & 58 & 63 \\
\hline $\begin{array}{c}\text { Classification } \\
\text { (USCS) }\end{array}$ & ASTM D 2487 & CL & CH \\
\hline $\begin{array}{c}\text { Organic Material } \\
\text { (O.M) (\%) }\end{array}$ & ASTM D 2974 & $<0.01$ & $<0.01$ \\
\hline $\begin{array}{c}\text { Calcium Oxide } \\
\text { (CaO) (\%) }\end{array}$ & $\begin{array}{c}\text { Chemical } \\
\text { Analysis }\end{array}$ & 18.38 & 21.12 \\
\hline SO3 Content (\%) & $\begin{array}{c}\text { Chemical } \\
\text { Analysis }\end{array}$ & 0.82 & 0.38 \\
\hline $\begin{array}{c}\text { Total Dissolved } \\
\text { Salt (TDS \%) }\end{array}$ & $\begin{array}{c}\text { Chemical } \\
\text { Analysis }\end{array}$ & 2.21 & 1.73 \\
\hline $\begin{array}{c}\text { Total Solved Salt } \\
\text { (TSS \%) }\end{array}$ & Analysis & 8.3 & 6.89 \\
\hline PH Value (\%) & ASTM D 4972 & 7.95 & 8.69 \\
\hline MDD (KN/m3) & ASTM D 698 & 17.55 & 16.5 \\
\hline OMC (\%) & ASTM D 698 & 16 & 20.5 \\
\hline
\end{tabular}

\subsubsection{Types and properties of additives}

The cement used to be sulfate resistance Portland cement (type V) manufactured by (Al Jessir) factory made in Iraq. The type of lime was used quicklime (unhydrated) manufactured from limestone by the Alnoora factory in Kerbella governorate. Also, quicklime made in Iraq. Table (2) and (3) shows the Physical and chemical properties of the cement and quicklime, respectively. The tests have been conducted in Iraq Geological Survey/Central Laboratories Department.

Table .2. The Physical and Chemical Properties of the Cement.

\begin{tabular}{|c|c|}
\hline Index Property & Index Value \\
\hline \multicolumn{2}{|c|}{ Physical Properties } \\
\hline Specific gravity (G.S) & 3.15 \\
\hline $\begin{array}{c}\text { Compressive strength after } 3 \\
\text { days (MPa) }\end{array}$ & 17 \\
\hline $\begin{array}{c}\text { Compressive strength after } 7 \\
\text { days (MPa) }\end{array}$ & 26 \\
\hline Time of initial setting (minute) & 93 \\
\hline Time of final setting (hour) & 4.28 \\
\hline
\end{tabular}




\begin{tabular}{|c|c|}
\hline \multicolumn{2}{|c|}{ Chemical Properties } \\
\hline $\mathrm{SiO}_{2} \%$ & 19.79 \\
\hline $\mathrm{CaO} \%$ & 63.8 \\
\hline $\mathrm{MgO} \%$ & 3.19 \\
\hline $\mathrm{SO}_{3} \%$ & 2.15 \\
\hline $\mathrm{C}_{3} \mathrm{~A} \%$ & 3.27 \\
\hline L.O.I \% & 0.89 \\
\hline
\end{tabular}

Table 3. The Physical and Chemical Properties of the Quicklime.

\begin{tabular}{|c|c|}
\hline Index Properties & Index Value \\
\hline \multicolumn{2}{|c|}{ Physical Properties } \\
\hline Specific gravity (G.S) & 2.99 \\
\hline $\begin{array}{c}\text { Retained on Sieve \# 30 (\%by } \\
\text { weight) }\end{array}$ & 0 \\
\hline $\begin{array}{c}\text { Retained on Sieve \# 200 (\%by } \\
\text { weight) }\end{array}$ & 11 \\
\hline \multicolumn{2}{|c|}{ Chemical Properties } \\
\hline CaO \% & 92.3 \\
\hline Free Water (\%) & 0.08 \\
\hline IR (\%) & 2 \\
\hline SO $(\%)$ & 0.07 \\
\hline L.O.I (\%) & 25.3 \\
\hline
\end{tabular}

\subsection{Laboratory tests}

A series of laboratory tests consisting of Atterberg limits, compaction and consoildation were conducted on the two selected clayey soils. The combinations of Portland cement and quicklime ( $\mathrm{PC}$ and LQ) were used for stabilization of the two soils. The percentages of PC were $0,2,4,6,8$ and $10 \%$. While the percentages of LQ were 0,2 and 4\%. A total of 11 combinations based on soil $\mathrm{A}$ and soil $\mathrm{B}$ with mixed modes of stabilizers were studied (Table 4).

Table 4. Stabilizer combination scheme for stabilizing soils

\begin{tabular}{|c|c|c|c|}
\hline \multirow{2}{*}{ Designation } & \multicolumn{3}{|c|}{ Sample mixture (\%) } \\
\cline { 2 - 4 } & Soil & PC & LQ \\
\hline PC 0\% LQ 0\% & 100 & 0 & 0 \\
\hline PC 2\% LQ 2\% & 96 & 2 & 2 \\
\hline PC 4\% LQ 2\% & 94 & 4 & 2 \\
\hline PC 6\% LQ 2\% & 92 & 6 & 2 \\
\hline PC 8\% LQ 2\% & 90 & 8 & 2 \\
\hline PC 10\% LQ 2\% & 88 & 10 & 2 \\
\hline PC 2\% LQ 4\% & 94 & 2 & 4 \\
\hline
\end{tabular}

\begin{tabular}{|c|c|c|c|}
\hline PC 4\% LQ 4\% & 92 & 4 & 4 \\
\hline PC 6\% LQ 4\% & 90 & 6 & 4 \\
\hline PC 8\% LQ 4\% & 88 & 8 & 4 \\
\hline PC 10\% LQ 4\% & 86 & 10 & 4 \\
\hline
\end{tabular}

\subsubsection{Atterberg limits tests}

According to ASTM D4318 (2000) can be obtain on plastic limit (PL), liquid limit(LL) and plasticity index (PI). Where studied in this research the plasticity index(PI) whether be treated or untreated soils by used a composite from PC and LQ. initially, the dry soils by airs (passing \# 40 sieves) and mix with the predetermined quantity of a composite (PC \& LQ) in a dry state together. add distilled water to the soil admixture. Permit water penetration into the soils and the mixing, the paste was allowed stand in an air tight container for about 24 hours to examining. After this calm, the paste was remixed with each stabilizer thoroughly for at least $15 \mathrm{~min}$ before the performance the first test. The plastic limit tests conducted on material prepared for the liquid limit test the plastic limit was determined as the average of the three water contents and rounded to the nearest whole number.

\subsubsection{Compaction tests}

The method given in the ASTM D558 (2000) was applied to determine the maximum dry density and water content which represents (OMC) of the soils. The soil mixtures, with and without additives, were thoroughly mixed for 0.5 hour before process the compaction the first of compaction tests were aimed at determining the compaction properties of the soils sample only. Secondly, tests were performed to determine the proctor compaction properties of the treated soil with varying amount of PC \& LQ.

\subsubsection{Consolidation test}

Odometer tests were performed according to ASTM D 2435. The simple size with a diameter of $7.5 \mathrm{~cm}$ and height $1.9 \mathrm{~cm}$ were put in the consolidation cells. The soil was mixed with different a composite content mentioned in the table (4). The soil samples were enclosed in a metal ring and placed into the consolidometer. The sample was sandwiched between two filter plates allowing a two-way drainage of the sample. Water was added into the cell around the sample, so the sample remained saturated during the test. Seven vertical static load increments were applied. The changes in the displacement of the sample against time were recorded during each loading increment. 


\section{Results and discussion}

\subsection{Atterberg limits}

Figure (2) and (3) illustrate the influence of both compounds on the plasticity index of soil A and $\mathrm{B}$ respectively. The addition of $2 \% \mathrm{LQ}$ and $\mathrm{PC}$ at a maximum value of $10 \%$, resulting in a decrease in liquid limit from $48 \%$ to $41.3 \%$ for soil $\mathrm{A}$ and from $58 \%$ to $49 \%$ for soil B, plastic limit increased from $21 \%$ to $32 \%$ and from $27 \%$ to $38.6 \%$ in soil A and soil B respectively. Hence, plasticity index decreased from $27 \%$ to $9.2 \%$ and from $31 \%$ to $10.3 \%$. On the other hand, the addition of $4 \% \mathrm{LQ}$ and $\mathrm{PC}$ at a maximum value of $10 \%$ result in also a decrease in liquid limit from $48 \%$ to $40 \%$ for soil A and from $58 \%$ to $47.1 \%$ for soil B, plastic limit increased likewise from $21 \%$ to $33.7 \%$ and from $27 \%$ to $40.4 \%$ for soil A and soil B respectively. Furthermore, plasticity index decreased as well from $27 \%$ to $6.3 \%$ and from $31 \%$ to $6.7 \%$ for soil $\mathrm{A}$ and soil $\mathrm{B}$ respectively. The reduction in the plasticity index is attributed to the transformation in soil nature (granular nature after flocculation and agglomeration) and the resulted soil is as crumbly as sandy clay soil. Many researchers illustrated that the decrease in the liquid limit of additive - treated soil depends on the soils type (Jawad et al, 2014) ${ }^{15}$. Table (5) Summaries of Atterberg limits values of soil A and B mixed with different percentages of composite.

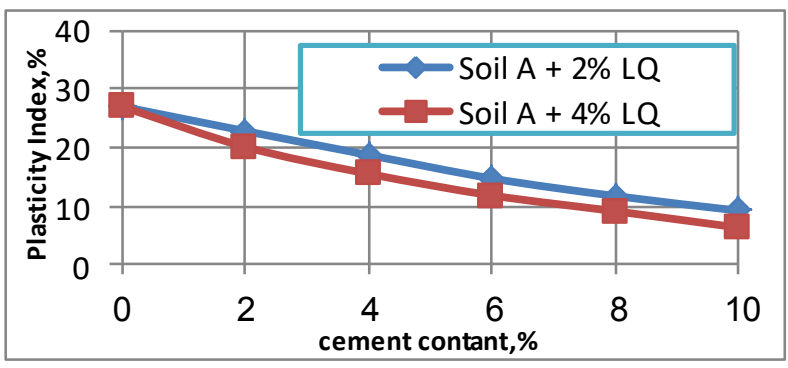

Fig. 2.Plasticity index for natural and treated soil A with different (PC, $\%$ LQ and 4\% LQ)

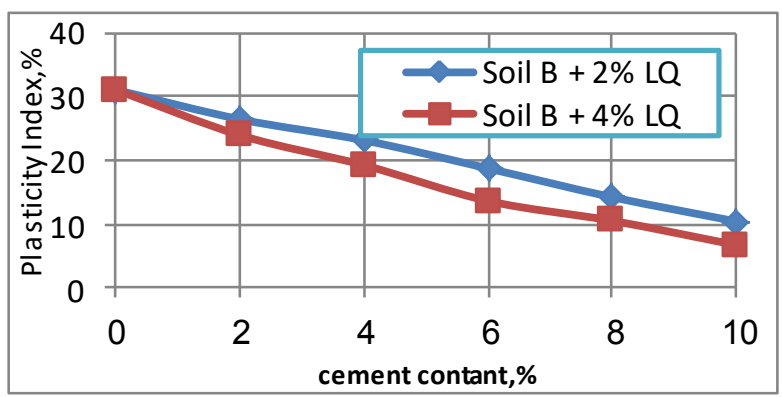

Fig. 3. Plasticity index for natural and treated soil B with different (PC, 2\% LQ and 4\% LQ)
Table 5. Atterberg limits values of soil A and B mixed with different percentages of composite

\begin{tabular}{|c|c|c|c|c|c|c|c|}
\hline \multicolumn{2}{|c|}{$\begin{array}{c}\text { The } \\
\text { Additive }\end{array}$} & \multicolumn{3}{|c|}{ Soil A } & \multicolumn{3}{|c|}{ Soil B } \\
\hline $\begin{array}{c}\% \\
\text { LQ }\end{array}$ & $\begin{array}{l}\% \\
\mathbf{P} \\
\mathrm{C}\end{array}$ & $\begin{array}{c}\% \\
\text { P.L }\end{array}$ & $\begin{array}{c}\% \\
\text { L.L }\end{array}$ & $\begin{array}{l}\% \\
\text { P.I }\end{array}$ & $\begin{array}{c}\% \\
\text { P.L }\end{array}$ & $\begin{array}{c}\% \\
\text { L.L }\end{array}$ & $\begin{array}{l}\% \\
\text { P.I }\end{array}$ \\
\hline 0 & 0 & 21 & 48 & 27 & 27 & 58 & 31 \\
\hline 2 & 2 & 24 & 46.8 & 22.8 & 30.9 & 57.3 & 26.4 \\
\hline 2 & 4 & 26.3 & 45 & 18.7 & 32.7 & 55.8 & 23.1 \\
\hline 2 & 6 & 29 & 43.7 & 14.7 & 35.1 & 53.8 & 18.7 \\
\hline 2 & 8 & 30.9 & 42.6 & 11.7 & 37.4 & 51.6 & 14.2 \\
\hline 2 & 10 & 32 & 41.3 & 9.2 & 38.6 & 49 & 10.4 \\
\hline 4 & 2 & 26 & 46.1 & 20.1 & 32.2 & 56.1 & 23.9 \\
\hline 4 & 4 & 28.9 & 44.4 & 15.5 & 34.8 & 54 & 19.2 \\
\hline 4 & 6 & 30.9 & 42.7 & 11.8 & 37.6 & 51.2 & 13.6 \\
\hline 4 & 8 & 32.7 & 41.8 & 9.1 & 39.3 & 49.8 & 10.5 \\
\hline 4 & 10 & 33.7 & 40 & 6.3 & 40.4 & 47.1 & 6.7 \\
\hline
\end{tabular}

\subsection{Compaction Characteristics}

Twenty two from both natural, untreated soils and treated soils with different percentages of PC and LQ were prepared to recognize the effect of compound admixture on the compaction properties. Figures (4) and (5) show the relationship between the maximum dry unit weight (MDD), moisture content (OMC) and different PC content for soils A and $\mathrm{B}$ with a $2 \% \mathrm{LQ}$, while Figures (6) and (7) present the effect commingle of 4\% LQ and 2 to $10 \%$ PC on the optimum water content and the maximum dry unit weight (MDD) of the two treated soils. When the adding the composite (PC \& LQ) can be seeing that increase the optimum moisture content and decreased the dry unit weight with increasing composite (PC \& LQ) content. Similar behavior was also observed in the literature in the case of composite (PC \& LQ) stabilized clayey soils. The showing of this behavior is maybe as a result of the following reasons: (1) the composite (PC and LQ) causes aggregation of the particles to occupy large spaces and hence change the effective category of the soils. (2) The pozzolanic reaction between the clay present in the soils and the composite is responsible for the increase in OMC. 


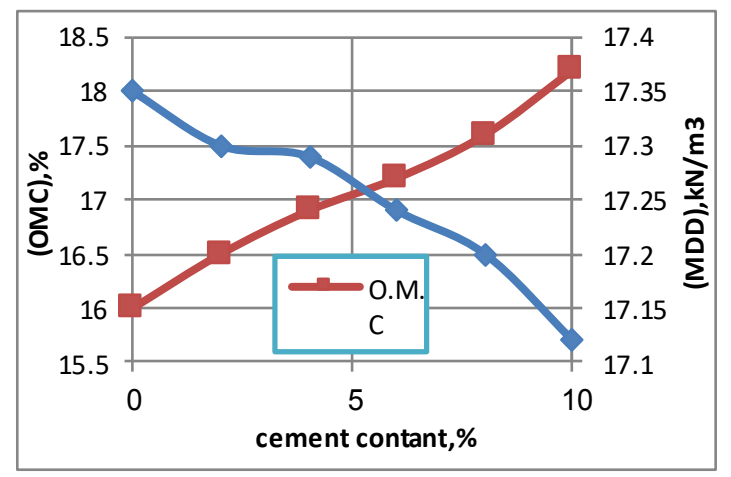

Fig .4. Relationship between MDD and OMC soil A with different $\mathrm{PC}$ and $2 \%$ LQ

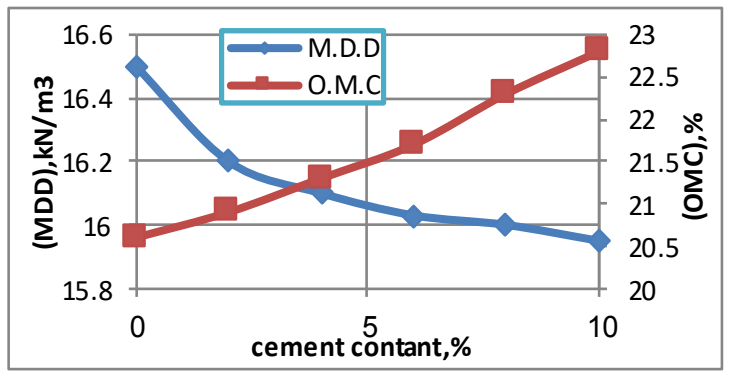

Fig. 5. Relationship between MDD and OMC soil B with different $\mathrm{PC}$ and $2 \% \mathrm{LQ}$

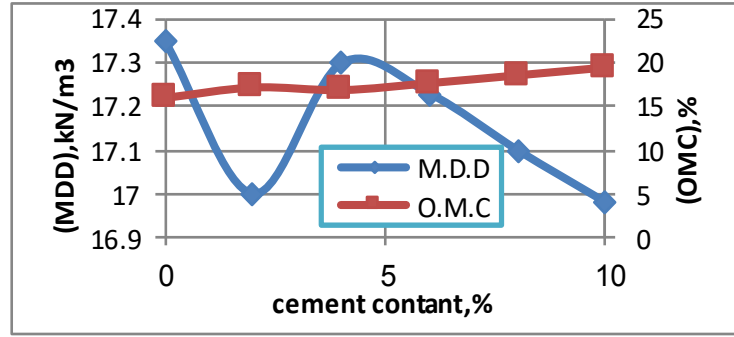

Fig. 6. Relationship between MDD and OMC soil A with different PC and 4\% LQ

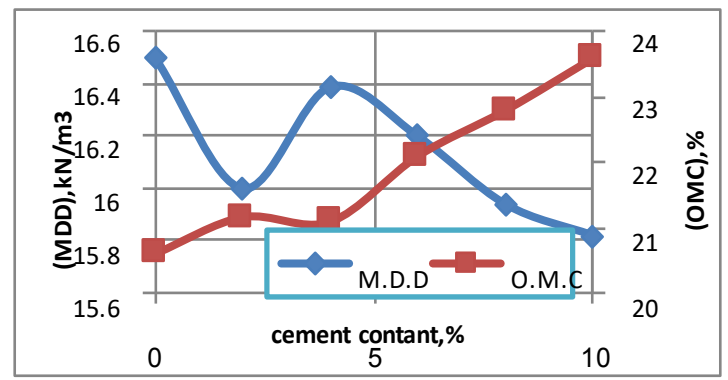

Fig. 7. Relationship between MDD and OMC soil B with different PC and $4 \%$ LQ

\subsection{Consolidation test}

The (The relation between compression and compression index is not a direct relation, and the compression index $(\mathrm{Cc})$ does not represent the compressibility of the soil. Wesly, $(1988)^{13}$ mentioned that the compression ratio (CR) is more realistic to find out the compressibility value, which it is;

$$
\mathrm{CR}=\mathrm{Cc} /\left(1+\mathrm{e}_{\mathrm{o}}\right)
$$

In contrast, the Rebound (Swelling) ratio (RR) is more accurate than the swelling index $(\mathrm{Cr})$, Where;

$$
\mathrm{RR}=\mathrm{Cr} /\left(1+\mathrm{e}_{\mathrm{o}}\right)
$$

The confined compressibility

$$
(\mathrm{mv})=(((1+\mathrm{v})(1-2 \mathrm{v})) /(1-\mathrm{v}) \mathrm{Es})
$$

The confined (one dimensional) compressibility is also referred to as the coefficient of volume compressibility or the coefficient of volume decrease and the symbol (mv) is widely used to indicate the value of this compressibility.

Results of consolidation tests for the twenty two samples. Figures (8) and (9) show the relationship between compression ratio (CR) and rebound (swelling) ratio (RR) with different $\mathrm{PC}$ and $2 \% \mathrm{LQ}$ for soils A and B respectively. It can be noticed that the additive of $2 \%$ LQ content can improve the compressibility of soft clay soils by reducing the compression ratio $\mathrm{CR}$ from 0.1264 to 0.0167 and from 0.1106 to 0.034 for soil A and B respectively. And the rebound (swelling) ratio RR decreased from 0.03 to 0.0027 and from 0.02518 to 0.0024 for soils A and B respectively.

Figures (10) and (11) show the relationship between compression ratio (CR) and rebound (swelling) ratio (RR) with different PC and 4\% LQ for soils A and B respectively. Results of consolidation test under the compound stabilizer indicate that composite at 4\% LQ can decrease the compression ratio $\mathrm{CR}$ of soft clay from 0.1264 to 0.0083 and from 0.1106 to 0.0058 for soil A and B respectively. While the rebound (swelling) ratio RR decreased from 0.03 to 0.00207 and from 0.00343 to 0.00094 for soil A and B respectively. This is due to the flocculation and cementitious phenomenal effects by the pozzolanic reaction that forms the secondary minerals (CSH). And it may also due to the formation of inter particle cementation bonds that improved the strength and reduced the compressibility. Furthermore, according to Baquir (1990) ${ }^{14}$ this behavior could be attributed to the presence of additive (cement + lime) within the soil, whose crystallization structure has extremely strong structural bonds. This indicates the increased tendency of clay additive blends to resist the compression and expansion. It is also attributed to the aggregate formation of soil treated with an additive which resulted in stronger particle aggregates and gave higher resistance to compression. Also, because 
used cement type $\mathrm{V}$ (sulfate resistance) causes for the decrease in the compressibility index $\mathrm{Cc}$ and swelling index $\mathrm{Cr}$ values may be attributed due to sulfate content $\left(\mathrm{SO}_{3}\right)$. Where Sulfate could possibly interact with the free lime and hence expansive minerals (ettringite crystals) will be formed. It could destroy the structure of soft soils and hence the soil structure becomes weaker, more compressible and a potential to expand (Nicholson, $2015)^{16}$. Through the figures and the valuses of CR and RR above and also observed bahaviour of untreated and treated soils assume poisson ratio for untreated soil is 0.4 and 0.2 for treated soil through these imposed values for poisson ratio have been calculate the modulus of elasticity (Es).

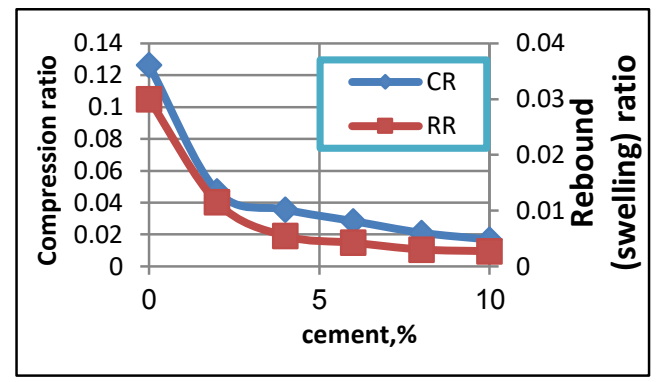

Fig. 8. The relationship between compression ratio (CR) and rebound (swelling) ratio (RR) with different $\mathrm{PC}$ and $2 \% \mathrm{LQ}$ for soils A

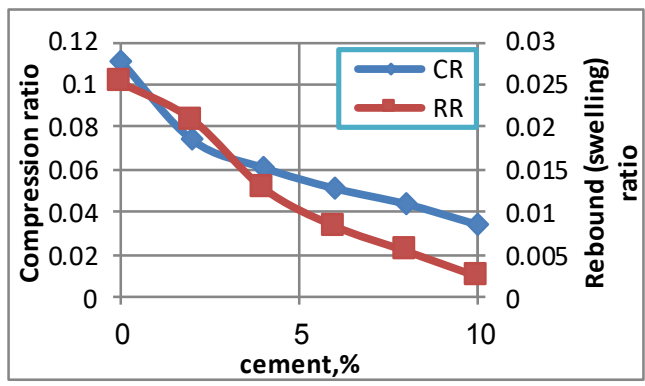

Fig. 9. The relationship between compression ratio (CR) and rebound (swelling) ratio (RR) with different PC and 2\% LQ for soils B

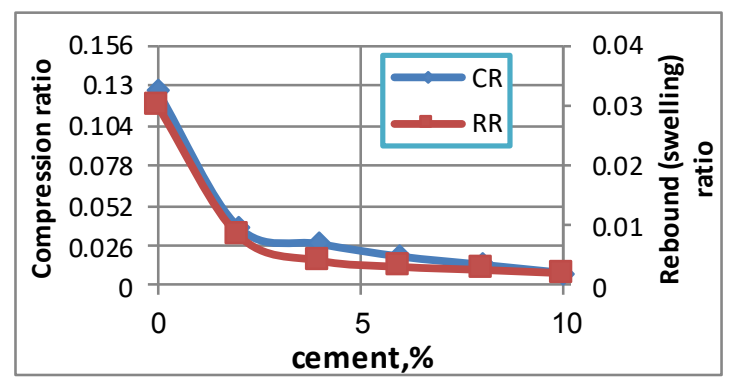

Fig. 10. The relationship between compression ratio (CR) and rebound (swelling) ratio (RR) with different $\mathrm{PC}$ and $2 \% \mathrm{LQ}$ for soils A

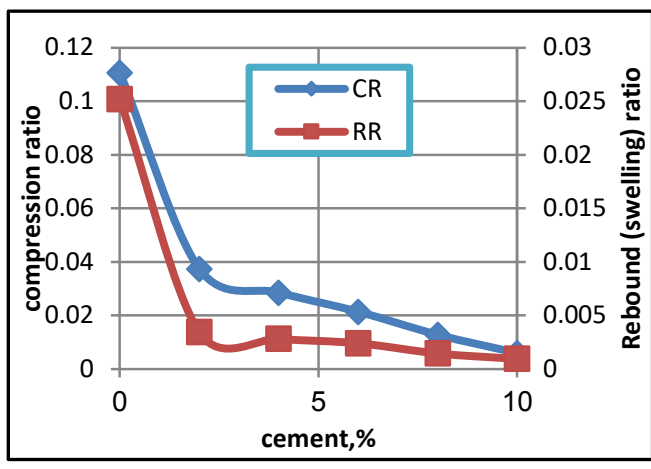

Fig. 11.The relationship between compression ratio (CR) and rebound (swelling) ratio (PR) with different PC and $\%$ LQ for soils B

This decrement shows that the soil samples were effectively stabilized, which indicates an improvement in the engineering properties of the soils by making them good non - plastic subgrade materials. This will considerably reduce the subbase and surfacing materials needed for road construction work. Table (6) summarized the results of consolidationtest. 
Table 6. Results of the compression index (Cc), Compression ratio(CR) swelling index (Cr), Rebound (Swelling) ratio (RR), The confined compressibility (mv) and the modulus of elasticity (Es) for soils mixed with different percentages of Additive (PC \& LQ) (A (soil A) and B (soil B))

\begin{tabular}{|c|c|c|c|c|c|c|c|}
\hline \multicolumn{6}{|l|}{ The Additives } & \multicolumn{5}{l}{ Soil A } \\
\hline PC \% & LQ\% & Cc & Cr & CR & RR & mv $\left(\mathrm{m}^{2} / \mathrm{kN}\right) * 10^{-5}$ & Es $\left(\mathrm{kN} / \mathrm{m}^{2}\right)$ \\
\hline 0 & 0 & 0.209 & 0.052 & 0.1264 & 0.03 & 9.55 & 4815 \\
\hline 2 & 2 & 0.078 & 0.019 & 0.0471 & 0.0114 & 3.58 & 25140 \\
\hline 4 & 2 & 0.059 & 0.009 & 0.0356 & 0.00543 & 2.7 & 33337 \\
\hline 6 & 2 & 0.047 & 0.0076 & 0.0283 & 0.00421 & 2.14 & 42053 \\
\hline 8 & 2 & 0.035 & 0.0052 & 0.0209 & 0.003 & 1.58 & 56911 \\
\hline 10 & 2 & 0.028 & 0.0043 & 0.0167 & 0.0027 & 1.2 & 71170 \\
\hline 2 & 4 & 0.068 & 0.014 & 0.037 & 0.00839 & 2.86 & 31448 \\
\hline 4 & 4 & 0.047 & 0.007 & 0.027 & 0.0041 & 2.06 & 43696 \\
\hline 6 & 4 & 0.031 & 0.005 & 0.0189 & 0.00312 & 1.422 & 63262 \\
\hline 8 & 4 & 0.022 & 0.0041 & 0.0136 & 0.00262 & 1.024 & 87859 \\
\hline 10 & 4 & 0.011 & 0.003 & 0.0083 & 0.00207 & 0.62 & 143161 \\
\hline
\end{tabular}

(B)

\begin{tabular}{|c|c|c|c|c|c|c|c|}
\hline \multicolumn{5}{|c|}{ The Additives } & \multicolumn{5}{|c|}{ Soil B } \\
\hline PC \% & LQ\% & Cc & Cr & CR & RR & $\mathrm{mv}\left(\mathrm{m}^{2} / \mathrm{kN}\right) * 10^{-5}$ & Es $\left(\mathrm{kN} / \mathrm{m}^{2}\right)$ \\
\hline 0 & 0 & 0.196 & 0.044 & 0.1106 & 0.02518 & 8.326 & 5543 \\
\hline 2 & 2 & 0.131 & 0.037 & 0.0737 & 0.0208 & 5.5 & 19629 \\
\hline 4 & 2 & 0.108 & 0.022 & 0.0607 & 0.01275 & 4.58 & 23429 \\
\hline 6 & 2 & 0.091 & 0.014 & 0.05103 & 0.0083 & 3.84 & 27116 \\
\hline 8 & 2 & 0.078 & 0.0096 & 0.04372 & 0.00538 & 3.32 & 34979 \\
\hline 10 & 2 & 0.061 & 0.003 & 0.0340 & 0.002402 & 2.57 & 38865 \\
\hline 2 & 4 & 0.066 & 0.006 & 0.0373 & 0.00343 & 2.81 & 32011 \\
\hline 4 & 4 & 0.051 & 0.0052 & 0.028 & 0.0028 & 2.14 & 42011 \\
\hline 6 & 4 & 0.038 & 0.0039 & 0.02128 & 0.002408 & 1.6 & 55509 \\
\hline 8 & 4 & 0.023 & 0.0026 & 0.01268 & 0.001452 & 0.958 & 44160 \\
\hline 10 & 4 & 0.014 & 0.0017 & 0.0058 & 0.00094 & 0.44 & 204748 \\
\hline
\end{tabular}




\section{Conclusions}

This study presents the effect of PC and LQ on Atterberg limits, compaction and consolidation of soft clay (cohesive) soils. On the basis of the test results, the following conclusions can be drawn:

1. Observes to reduce the rate of dehydration of the soil when adding small amounts of the compound (PC \& LQ). Also, notes the effect of the dehydration rate increase soil when adding high levels of the compound in the initial period during the first half hour at add the mixture to the soil.

2. The addition of a few percentage PC and LQ cause low decreased in plasticity index, while a higher percentage of the composite (PC \& LQ) led to a reduction in plasticity index. Thus, PC \& LQ added soils have better workability.

3. The addition PC \& LQ increased optimum water content and decreased maximum dry unit weight of the soils.

4. The addition of the composite (PC and LQ) to the sample soils can improve the compressibility of soft clay soils by reducing the compression ratio (CR) from 0.1185 to 0.00705 (as averages for both soils), also reduction in rebound (swelling) ratio from 0.0276 to 0.0015 (as averages for both soils) was observed with increasing composite $(10 \%$ PC and 4\% LQ).

5. Through observe increment in the modulus of elasticity (Es) from $5179 \mathrm{kN} / \mathrm{m}^{2}$ to 173954.5 $\mathrm{kN} / \mathrm{m}^{2}$. PC \& LQ treated soils exhibited much more brittle behavior compared with non treated soils.

\section{References}

1. E.W. Brand, and R.P., Brenner, Elsevier Scientific Publish Company, Amsterdam. (1981)

2. British Standard B.S: C.P. 8004 "Code of Practice for Foundation ", British Standard Institution, London. (1986)

3. B.B., Broms, Proceeding 5th International Geotechnical Seminar 2 - 4 Dec. (1987)

4. E., Cokça, Electronic Journal of Geotechnical Engineering, Paper 9904. Oklahoma State University, USA. (1999)

5. G.N., Obuzor, J.M., Kinuthia and R.B. Robinson, Eng. Geol. 122 (3-4), 334-338. (2011)

6. E., Pomakhina, D., Deneele, A.-C., Gaillot, M., Paris, G., Ouvrard, Res. 42 (4), 626-632. (2012)

7. F. Sariosseiri, and B. Muhunthan, Journal of Engineering Geology Vol.104, pp.119-125. ,(2009)

8. D.D., Currin, J.J., Allen, D.N., Little, Report No. FJSRL-TR-0006. Frank J. Seisler Research
Laboratory, United States Air Force Academy, Colorado. (1976)

9. D.O. Osula,., Eng. Geol. 42 (1), 71-81. (1996).

10. S., Bin, L., Zhibin, Yi, C., Xiaoping, Z.,.. Civ. Eng. 19 (1), 99-104. (2007)

11. Z., Metelkova, J. Bohac, , R., Prikryl, I., Sedlarova, Appl. Clay Sci. 61, 37-43. (2012)

12. J. Locat, , M.-A., Bérubé, M., Choquette Can. Geotech. J. 27, 294-304. ,(1990)

13. Wesley, D Laurence.". Journal of Geotechnical Engineering 114.6 718-723. (1988)

14. H.H., Baquir, "Stabilization of Fao Clay", M.Sc. thesis, University of Technology. (1990)

15. I.T., Jawad, , Research Journal of Applied Sciences, Engineering and Technology, Maxwell Scientific Organization, Vol.8, No. 4, pp:510-520. (2014)

16. P.G., Nichloson, Elsevier Scientific Publish Company, Amsterdam. (2015), 